\title{
MEMBANGUN KONSTRUKSI KEILMUAN EKONOMI ISLAM
}

\author{
Yulizar D. Sarreg Nz*
}

\begin{abstract}
Theories of Idamiceconomics haveformed part and parced of thegdbal study on economy. Pradicallyon theother hand, Idamiceconomics haveshownits competingabilityand recived in tum a dheeful udconefirom thebusiness community as wdl as from themasses at thegdbal stage This peper is an attempt tomakea contribation in thefiedd of what wemay call the sientific construation of Islamic economics. The paper proposes that this sience consists of twoaspets, namily valueandknowketge With regards to thelatter, on which this paper will payitsmajor attention, therdeof mothoodogy is couaal. This paper will thetore tarch on this issueand therde of mothoddoy in inventing knowkedgeandin theanalysis of economic datum Hereby mothoddogy wemean partiallarly figh. Wecontend that fiqh is in itsdf methoddogy. It is nich with mthodblogical tools such as the concept of macashid alsyaniah (thepurposeof divinelaw) which may beused not onlytoanalyzeeconomicdatumbut alsotoproidea shematain resdvingsomeeconomicproblems Byspeakingoffichasasiene of economiss we hope to pave the vay for the possibleinvention of the siene of economics basedonfiqhanditsphilosphy.
\end{abstract}

Keywords: Idamiceconomics, mthoddogy, fiqh

\section{Pendahuluan}

Ekonomi Islam merupakan bagian integral dari sistem ajaran Islam. Dia merupakan ekonomi ilahiah, karena titik berangkatnya dari Allah, tujuannya mencari ridaxAllah dan cara-caranya tidak bertentangan dengan shari'at-Nya. ${ }^{1}$ Ia bukan lahir sebagai produk alternatif dari sistem yang sedang berlaku sekarang (baca sosialis maupun kapitalis), tetapi merupakan sumat Allah (ketetapan Allah) yang seharusnya diaplikasikan di sepanjang lembaran sejarah peradaban manusia. Bisa dinyatakan bahwa sebetulnya Ekonomi Islam adalah sebuah sistem yang sudah ada semenjak Islam diturunkan di tanah Arab. Hal tersebut bisa diyakinkan dengan praktek Rasulullah Saw yang menjadikan nilai-nilai Qur'ani sebagai rujukan dalam menentukan pilihan atau kegiatan ekonominya (economicbdhaviar). Begitu pula yang dilakukan oleh para pengikutnya setelah kepergian beliau; nilai-nilai ilahiah maupun sunnah beliau merasuki pola perilaku dan diaplikasikan dalam bentuk transaksi ekonomi.

D engan kata lain, sistem ekonomi Islam merupakan sistem ekonomi yang merujuk kepada prinsip-prinsip nilai Islam. Secara filosofis, nilai-nilai tersebut berdasarkan kepada bagaimana manusia memahami dengan baik pandangan dunia Islam-nya (Rưyat al-Isamli al-Wujud Isamic Woddkient. Ada empat hal fundamen yang memberikan pengaruh sangat besar umat manusia dalam cara mereka ber-ekonomi; (1) Konsep Tanhild (2) Konsep Nubumwah(3) Konsep Khalifah (4) Konsep Alam semesta (lihat pembahasan pada sub-bab 1.4). Artinya, pemahaman yang komprehensif tentang pokok-pokok di atas akan memberikan

\footnotetext{
* Lembaga Penelitian dan Pemberdayaan Masyarakat (LPPM) Sekolah Tinggi Ekonomi Islam TAZKIA, Jl. Raya Bogor. Email: senapatie@ yahoo.com

${ }^{1}$ Y usuf al-Q ardhawi, PeranNilai danMoral dalamPerkanomianIdam(Jakarta: Robbani Press), 2001.
} 
arah yang jelas bagaimana seharusnya melakukan aktivitas-aktivitas ekonomi. Pada pemahaman ini ingin menegaskan bahwa proses terjadinya aktivitas ekonomi merupakan sumat Allah ketika manusia diciptakan di satu sisi dan penyediaan alam beserta isinya di sisi lain dalam rangka bertahan hidup dan mencapai kesejahteraan hidupnya.

Upaya untuk terus melakukan aktivitas ekonomi berbasis nilai terus berlanjut sehingga terbangun kultur akademis dalam sejarah ekonomi Islam. ${ }^{2}$ Kultur akademis tersebut ditandai dengan munculnya beberapa ulama Islam yang mencoba memberikan lontaran pemikiran atau konsep yang berkaitan dengan praktek-praktek ekonomi pada masanya masing-masing. Abu Yusuf, Abu Ubaid, Yahya bin Adam merupakan generasi awal dalam sejarah pemikiran ekonomi Islam yang memberikan respon melalui pemikirannya terhadap praktek-praktek ekonomi pada masanya. Pada saat itulah bisa dikatakan bahwa ekonomi Islam sebagai sebuah ilmu (sistem analisis) mulai mengemuka dan mentradisi dalam sejarah ekonomi Islam. ${ }^{3}$ Ini menegaskan pernyataan Anas Zarqa yang memetakan ekonomi Islam menjadi dua bagian yang saling terkait (1) Ekonomi Islam sebagai sebuah sistem nilai (2) Ekonomi Islam sebagai sebuah Ilmu (sistem analisis). ${ }^{4}$

Kalaulah isu atau wacana ekonomi Islam muncul kembali pada saat sekarang ini khususnya awal tahun 90-an karena disebabkan oleh dua hal, (1) runtuhnya kesultanan Turki Uthmani yang menandai runtuhnya peradaban Islam (2) penjajahan yang dialami oleh mayoritas negara-negara muslim. Yang disebut terakhir pada gilirannya berdampak pada pemahaman dikotomi ilmu dalam dunia Islam antara ilmu agama di satu sisi dan ilmu pemerintah di sisi yang lain. Fakta ini yang kemudian memberikan dampak besar terhadap kemandekan kultur akademis/ ilmiah di dunia Islam termasuk dalam bidang ekonomi (khususnya kajian tentang figh múamalah al-moliyah). Nada yang sama juga dinyatakan oleh M. A. Mannan dalam pembahasan garis besar sejarah peradaban Islam: Pertumbuhan, Perkembangan dan Kemunduran. ${ }^{5}$ Tulisan ini mencoba mengangkat isu-isu fundamental ekonomi Islam sebagai bentuk upaya untuk merumuskan konstruksi keilmuan ekonomi Islam.

\footnotetext{
${ }^{2} \mathrm{D}$ alam hal ini akan terjadi proses di mana dalam upaya mendapatkan atau mencapai kesejahteraan akan terjadi upaya penemuan konsepsi atau kebijakan perilaku (strategi) yang sepatutnya dilakukan dalam rangka mencapai kesejahteraan tersebut. Konsepsi atau kebijakan perilaku tersebut merangkumi perilaku ekonomi umat manusia, baik di dalam analisa mikro maupun makro. Proses yang berkelanjutan dalam penemuan konsepsi perilaku ekonomi inilah yang kemudian menuntut terbangunnya kultur akademis dalam rangka mencapai kesejahteraan sejalan atau sebagai respon dari perubahan aktivitas ekonomi manusia yang dinamis.

${ }^{3}$ Sesungguhnya lontaran pemikiran atau konsep yang berkaitan dengan aktivitas ekonomi sudahpun berlangsung semenjak masa Rasulullah Saw maupun Khulafaלal-Rashidir. Bagaimana Baginda Rasul membangun lembaga pasar di awal pemerintahannya sebagai bagian dari infrastruktur yang memastikan terjadinya perputaran ekonomi termasuk kebijakan Umar r.a yang mendirikan Baytal-Mal?Respon terhadap tantangan ekonomi tersebut menguat menjadi tradisi ilmiah pada abad ke-2 Hijrah ketikaAbu Y usuf menawarkan konsep ekonomi melalui bukunya alKharaj.

${ }^{4}$ Muhammad Anas Zarqa, "Islamization of Economics: The Concept and Methodology," J.KAU., Vol. 16, No.1, pp. 3.42 (1424 A.H/ 2003 A.D ). Baca juga pembahasan M.A. Mannan dalam bukunya Ekonomi Isam Teer dan Praktdk, terj (Jakarta: PT. Intermasa), tt. 15-16.

${ }^{5}$ Lihat Muhammad Abdul Mannan, The Making of IslamicEconomicSoidy(Jeddah-Saudi Arabia: International Center for Research in Islamic E conomics, King Abdul Aziz University (KAU), 1984/ 1404H.), 16-19.
} 


\section{Definisi dan Metodologi Ekonomi Islam}

Sebelum membahas lebih lanjut tentang definisi maupun metodologi ekonomi Islam, ada baiknya untuk mendiskusikan pertanyaan mengapa harus ilmu ekonomi Islam? Tentunya pemahaman dari pertanyaan ini sudah mengakomodir pemahaman yang membedakan pengertian ekonomi Islam sebagai sebuah ilmu maupun sistem nilai yang dinyatakan oleh Anas Zarqa pada pembahasan sebelumnya. Merujuk kepada M. A. Mannan, bahwa paling tidak ada tujuh alasan mengapa ilmu ekonomi Islam penting untuk dipelajari dan dikembangkan oleh sarjana Muslim. ${ }^{6}$

Petama, kepentingan ideologi (idedogical imperatives). Kebutuhan mempelajari ilmu ekonomi Islam sebagai sebuah cabang ilmu pengetahuan memiliki sumber asli terhadap konsep ideologi Islam, dibangun oleh Idamic voddkiew nilai dan norma. Gagasan-gagasan dan nilai ini tidak hanya diderivasikan baik langsung maupun tidak langsung melalui al-Qur'an dan al-Sunnah, tetapi juga ijmasdan ijtihad.

Keelua, kepentingan ekonomi (economic imperatives). Studi ilmu ekonomi Islam muncul sebagai jawaban praktik yang diperlukan untuk mencari jalan ke luar dari krisis dan konflik pembangunan dan proses modernisasi yang telah diawali di dunia Muslim. Para ekonom Muslim berusaha untuk menemukan solusi secara Islami bagi masalah pengembangan ekonomi dan keuangan modern.

Keiga, kepentingan sosial (social impeatives). Kebutuhan mempelajari ilmu ekonomi Islam datang karena perhatian Islam pada bidang sosial dalam ekonomi pembangunan dan perencanaan.

Keempat, kepentingan moral dan etika (moral and thical imperatives). D alam studi ilmu ekonomi Islam, keputusan ekonomi dipengaruhi dan dibimbing oleh pertimbangan nilai (valuejudgemert) berdasarkan referensi nilai yang ada dalam al-Qur'an dan al-Sunnah, dengan demikian perbedaan-perbedaan tanda atau ciri tertentu yang mengesankan berada pada level pelaksanaanya.

Kdima, kepentingan politik (pditical imperatives). Alasan ini bukanlah independensi politik tetapi independensi ekonomi yang berasal dari para penjajah masa lalu pada dunia Muslim. D unia Muslim perlu identitas agar hal ini dapat membawa tanggungjawab internasional yang bisa ditanggung bersama.

Keenem perspektif sejarah (historical pespeetive). Studi ilmu ekonomi Islam diperlukan akan sebab-sebab sejarah juga. D unia Islam yang telah menjadi korban imperialisme telah menciptakan dan meninggalkan sebuah trapevolusi dan capdalam proses alamiah komunitas Islami (lihat gambar 1).

Ketujuh kepentingan internasional (intemational imperatives). Kegagalan sistem kapitalisme dan sosialime dalam menyelesaikan masalah undkedexdopment dan permasalahan kemiskinan yang besar di negara Islam khususnya dan negara berkembang umumnya, harus memungkinkan para ekonom Muslim mengidentifikasi medan kerjasama ekonomi di antara negara-negara Islam untuk menemukan solusi kebijakan sosio-ekonomi.

Untuk mengisi representasi gap banyak cendekiawan muslim kontemporer yang mencoba mengalokasikan waktunya untuk mengkaji maupun menulis tentang ekonomi Islam. Intinya, para cendekiawan muslim tersebut sepakat bahwa ekonomi Islam ada dan

${ }^{6}$ Ibid., 3-21. 
harus ada sebagai bentuk riil atau representasi nilai-nilai ilahiah (sumat Allab). Sebagaimana halnya disiplin ilmu lain, fungsi utama dari ekonomi Islam adalah merealisasikan kesejahteraan manusia melalui aktualisasi maqasji ${ }^{7}$

Salah satu bentuk kontribusi para cendekiawan adalah banyaknya tafsir berkenaan dengan definisi ekonomi Islam yang coba diutarakan oleh mereka. D ari beberapa definisi yang ada dapat disimpulkan bahwa ekonomi Islam mengandung dua pemaknaan sekaligus; yaitu sebagai sistem nilai maupun sebagai sistem analisis (ilmu). Untuk penjelasan yang terakhir, di mana proses analisa maupun kajian terus berlangsung, tentunya akan selalu bersinggungan dengan metodologi. D alam konteks ini, peran metodologi sangat signifikan dalam rangka mengembangkan analisa atau studi tentang ekonomi Islam dan segala turunannya.

Permasalahan metodologi pula yang menjadi sorotan kritis seorang al-Faruqi sebagai salah satu inti malaise umat Islam. Beliau menyatakan bahwa inti krisis di bidang politik, ekonomi dan budaya yang terjadi di kalangan umat Islam adalah berpangkal dari malaise pemikiran dan metodologi. ${ }^{8}$ Selain itu, umat ini telah kekurangan visi yang jelas di mana visi yang dipegang dan dikedepankan adalah visi-visi yang berasal dari Barat. Metodologi dalam pemahaman penelitian ini juga yang melahirkan Jepang sebagai negara maju. Penelitian yang berterusan dengan penggunaan metodologi yang tepat sangat berperan sentral dalam "memastikan" tujuan ekonomi sesuai dengan pesan-pesan Ilahiah maupun sesuai dengan kebutuhan masyarakat pada masa dan tempat tertentu.

Semetara itu, Anwar menegaskan bahwa metodologi ekonomi Islam harus membantu pada pengembangan ilmu ekonomi. O leh karena itu, ekonomi Islam harus mengembangkan teori-teori yang sesuai dengan doktrin ekonomi Islam dalam penemuan, eksplorasi, dan utilitas sumber-sumber materi di alam. Pertumbuhan dalam ilmu ekonomi dan disiplin lainnya harus mempertinggi pemahaman Rahmat Allah dalam penciptaan alam semesta, dan membantu manusia mengeskploitasi alam semesta untuk kebaikan manusia. Oleh sebab itu, penemuan ilmu pengetahuan harus memfasilitasi pencarian keridhoan Allah Swt. ${ }^{9}$

Chapra mempunyai pembahasan khusus tentang metodologi dalam bukunya yang berjudul What is Isamic Economics (1996). Kata metode mengacu pada "following a path" atau langkah-langkah spesifik yang harus dilakukan untuk mencapai tujuan tertentu. Sifat dari langkah-langkah berikut rincian detail spesifikasi tersebut tergantung kepada tujuan akhir dan beragam cara untuk mencapainya. ${ }^{10}$ Secara teknis, metodologi mengacu kepada thetednical procedures of a disaipine ${ }^{11} \mathrm{~A}$ pa yang harus disempurnakan dalam metodologi adalah "menyiapkan kriteria atau standar untuk menerima atau menolak riset-riset yang dilakukan, menetapkan kriteria yang akan memudahkan kita untuk memahami antara tepung dan gandum". ${ }^{12}$

Walaupun secara definisi menginginkan adanya kepastian "a path" untuk dijalani,

\footnotetext{
${ }^{7}$ Mohammad Umar Chapra, What isIdamicEconomics' (Jeddah, Saudi Arabia: IRTI- ID B, 1996), 33.

${ }^{8}$ Ismail Raji al-Faruqi, Isamization of Knowkeebe Prodens, PiniplesandProspetive(USA:IIIT, 1982), 2-9.

${ }^{9}$ Mohammad Anwar, "Islamic Economic Methodology," dalam EssaysinIsamicEconomicA nalysised. FR. Faridi (New Delhi: 1991), 15.

${ }^{10}$ Peter Caws dalam Mohammad Umar Chapra, What isIdamicEconamis?, 36.

${ }^{11}$ Mark Blaug dalam Ibid., 36.

${ }^{12}$ Ibid., 37.
} 
akan tetapi pilihan penggunaan metodologi yang heterogen tidak bisa dielakkan. Hal ini terkait dengan pemaknaan tujuan ekonomi Islam yang tidak hanya untuk tujuan menerangkan atau memprediksi suatu keadaan akan tetapi lebih dari itu adalah kesejahteraan manusia. D alam konteks inilah menurut Chapra pluralisme metodologi (mthoobigical pluralism) menjadi cara paling cocok yang juga biasa digunakan oleh para sarjana ekonomi Islam di masa lalu..$^{13}$ Hal senada juga dinyatakan oleh Siddiqi bahwa "Islamic tradition in economics has been free of formalism, focusing on meaning and purpose with a flexible methodology. ${ }^{\prime 14}$ Tentunya pengertian bebas dari formalitas di sini tidak kemudian serta merta bebas dari nilai atau prinsip Islam maupun pencapaian tujuan akhir berupa kesejahteraan manusia seperti yang dinyatakan oleh Caws.

Paling tidak ada tiga tahap yang harus dilakukan untuk menerima atau menolak sebuah hipotesis yang ada. ${ }^{15}$ Petama, apakah hipotesis tersebut sesuai dengan struktur logika paradigma Islam atau shariła yang telah ada dalam al-Q ur'an maupun Sunnah Rasulullah Saw. Sebagaimana yang ditegaskan oleh Siddiqi, penggunaan al-Qur'an maupun Sunnah sebagai rujukan untuk menerima atau menolak hipotesis tidak bisa dihindarkan karena "kajian ekonomi Islam dimulai dengan pemahaman tentang tauhid dan nilai atau ajaran Islam dan tidak bisa dibayangkan tanpa ada pemahaman yang utuh tentang kedua hal tersebut." Walau bagaimanapun, peran akal (logical resoning dan intervensi manusia melalui proses ijtihadi masih layak mendapatkan tempat dalam melakukan proses metodologi tersebut selama tidak dinyatakan dengan jelas di kedua sumber hukum Islam tadi dan selama tidak membuka ruang konflik dengan al-Qur'an maupun Sunnah Rasulullah Saw.

Ketidakjelasan di dalam kedua sumber tersebut "mengharuskan" adanya langkah kedua dalam proses metodologi untuk mengevalusi sebuah hipotesis berupa peran logika akal yang masih berada dalam kerangka prinsip-prinsip shariłah. Langkah ketiga dalam proses metodologi ini adalah berupa analisa hipotesis terhadap data sejarah maupun data statistik yang berkaitan dengan kondisi masyarakat Muslim atau non-Muslim sekarang maupun yang telah lalu. Upaya evaluasi yang dilakukan tersebut adalah dalam rangka membangun sebuah teori sarat nilai yang mengarah kepada aktualisasi tujuan ekonomi Islam (maqas)id). Chapra menambahkan bahwa kajian ekonomi Islam memungkinkan untuk mengadopsi teori-teori ekonomi konvensional selama tidak bertentangan dengan struktur logika pandangan dunia Islam (Isamic Woldkiew). ${ }^{16}$

\section{Konstruksi Keilmuan dan Pengembangan Ekonomi Islam}

Sesungguhnya alur penetapan tujuan ekonomi berikut upaya-upaya untuk merealisasikan dan menjaga kesinambungannya perlu dibahas secara terpisah dan sistematis. Bagian ini mencoba untuk menggagas sebuah konstruksi keilmuan ekonomi Islam yang menggambarkan proses di mana ekonomi Islam sebagai sistem nilai dan sistem analisis (ilmu) berproses dalam rangka memastikan pencapaian falahlmaupun menjaga

\footnotetext{
${ }^{13}$ Ibid.,38.

${ }^{14}$ M. Nejatullah Siddiqi dalam Ibid., 38.

15Ibid., 38.

${ }^{16}$ Untuk mengetahui bahwa melakukan tes hipotesis adalah merupakan bagian integral dari tradisi Islam, baca Umer Chapra (What is Islamic Economics, 1996. ID B-IRTI Jeddah, Saudi Arabia).
} 
kesinambungannya bagi masyarakat sebagai bentuk tujuan ekonomi sebagaimana yang telah dibahas pada bagian sebelumnya.

Pembahasan ini dimulai dari pemahaman definisi ekonomi Islam yang dimaknai bahwa semua seluruh aspek kehidupan yang berkaitan dengan perekonomian harus sesuai dengan tuntutan Islam, yaitu al-Q ur'an dan al-Sunnah (Islamicidedogy). ${ }^{17} \mathrm{D}$ alam prakteknya, tuntutan atau prinsip-prinsip yang ada di dalamnya mewarnai segala aktifitas perekonomian serta menjadikannya sangat berbeda dari sistem ekonomi manapun. D alam konteks ini, sebuah konsep atau sistem ekonomi pada dasarnya dibentuk oleh sebuah ideologi tertentu yang menaunginya. Sehingga, bagaimana pandangan ideologi tersebut tentang segala sesuatunya (norddkiew akan sangat menentukan bagaimana sistem tersebut berjalan.

Pada titik ini, sistem ekonomi Islam dimaknai sebagai suatu sistem yang dibangun di atas pemahaman yang paripurna terhadap pandangan dunia Islam (Isamic Wordkiew) berdasarkan al-Qur'an dan al-Sunnah. Pandangan ini akan dijadikan kerangka rujukan untuk aturan maupun cara pandang terhadap permasalahan-permasalahan ekonomi, sehingga apapun hasilnya (formulasi, strategi, kebijakan dll) akan selalu seirama dan patuh terhadap nilai-nilai yang terkandung dalam al-Q ur'an dan al-Sunnah. ${ }^{18}$ Pemahaman Idamic Worddkiew ini bisa diawali dari pemahaman tentang konsep Tawhid Konsep tauhid memberikan pemahaman bahwa peran Allah Swt dalam seluruh aspek kehidupan perekonomian menjadi mutlak sifatnya. Pusat segala sesuatu aktivitas ekonomi berikut tujuannya adalah Allah Swt (theosentris) dan bukan atas kehendak manusia semata (antroposentis).

Konsep tauhid sendiri mempunyai dua turunan makna; Tawhid Ulub ${ }^{19}$ dan Tawhid Rubukiyah $^{20}$. D alam konteks ekonomi, manusia harus menyadari bahwa otaitas yang dimilikinya tidak lebih dari pemegang amanah, untuk mengolah dan mempergunakan apa yang telah dianugerahkan Allah untuk kebahagiaan umat manusia dan bukan kepentingan individual. Pada akhirnya konsep tauhid ini akan memberikan dampak kesadaran bagaimana seharusnya manusia menggunakan sumberdaya yang telah Allah anugerahkan kepada manusia, khususnya untuk pemahaman tawhid ulukiyah

Sumberdaya yang telah Allah anugerahkan seharusnya; petama, digunakan untuk kepentingan semua orang, tidak hanya untuk segelintir saja. Kedua, dicari dengan cara yang

\footnotetext{
${ }^{17}$ Ungkapan ini menegaskan bahwa ekonomi Islam sebagai ilmu tidak bebas nilai sebagai dipahami Barat (values free. Artinya, di dalam sebuah masyarakat Islam, nilai yang membentuk upaya sains dan teknologi haruslah nilai Islam, yang dalam istilah singkatnya disebut sebagai konsep sains Islam, Nasim Butt dalam Huzni Thoyyar, "Model-Model Integrasi dan Upaya Membangun Landasan Keilmua Islam." http:// www.ditpertais.net/ annualconference/ ancon06/makalah/ Makalah \% 20 Husni\% 20Thoyyar.pdf. D alam kerangka ini, tidak ada pemahaman dikotomis keilmuan antara deeni (reigious) sienes dan dunyawiłwardy) sienes (Lihat M. Amir Ali, "Removing the Dichotomy of Sciences: A Necessity for the G rowth of Muslims. Future Islam: A Journal of Future Ideology that Shapes Today the World Tomorrow." http:// www.futureislam.com/20050301/ amir ali?removing dichotomy of sciences.asp, 2004

${ }^{18}$ Sesungguhnya proses pengembangan konstruksi ekonomi Islam dalam konteks ini mengacu kepada model integrasi ilmu, di mana penulis lebih merapat pada konsep Islamisasi Ilmu Pengetahuan (IslamizationofKnoweelge) yang diusung oleh beberapa pemikir seperti Alparslan Acikgenc, Syed Hossein Nasr, Naquib al-Attas dan Ismail Raji al-Faruqi. Prinsipnya adalah bahwa teorisasi dalam bidang keilmuan ekonomi Islam harus mengakar kepada pandangan dunia Islam (IdamicWordV iens.

${ }^{19}$ TawhidUlukiyjah: keyakinan akan ke-E saan Allah dan kesadaran bahwa seluruh yang ada di bumi dan di langit adalah milik-Nya.

${ }^{20}$ TamhidRubukizah keyakinan bahwa Allah saja yang menentukan rizki untuk segenap makhluk-Nya dan Dia pulalah yang akan membimbing setiap insan yang percaya kepada-Nya ke arah keberhasilan.
} 
jujur dan benar, sesuai cara yang ditetapkan Allah Swt. Ketiga, pemanfaatannya harus amanah dan bertanggung jawab. Keempat, dilarang merusak sumberdaya dan menyia-nyiakannya.

Pemahaman kedua dari Isamic Wordkiew adalah konsep nubummah (kenabian). Pesan yang bisa kita ambil hikmah dari kehadiran para rasul maupun anbiya'sadalah bahwa mereka diutus dalam rangka mengesakan Allah $\mathrm{Swt}^{21}$ dan memberikan suri tauladan (Siddick Amarah, Fatabah Tabigh) dalam semua sisi kehidupan umat manusia. ${ }^{22}$ Pesan lain yang harus dipahami dengan adanya utusan Allah adalah sebagai wujud Rahmandan RabimAllah Swt. Jangankan manusia biasa, Nabi atau Rasul saja tidak "kuat" secara langsung mendapatkan pesan dari Allah Swt. D engan adanya utusan-Nyalah kita umat manusia bisa memahami bagaimana seharusnya berbuat sebagai khalifat Allah di muka bumi ini. Bagaimana seharusnya kita berperan sebagai hamba Allah ('Ibad Allab); bagaimana kita seharusnya berperan sebagai pemimpin, bagaimana pula seharusnya kita berinteraksi (muamalah) dengan makhluq yang lain.

Pemahaman ketiga dari IdamicWoddkiewadalah konsep khalifatAllahpada diri manusia. Selain memiliki tugas sebagai hamba Allah (Q.S. 51:56), manusia juga diberikan peran lain sebagai khalifatAllahfi sl-ard(wakil Allah di dunia). Peran untuk memakmurkan dan mengatur kehidupan dunia termasuk ekonomi sesuai dengan petunjuk Allah Swt (Q.S. 2.30). Peran kedua ini pada dasarnya merupakan bentuk ibadah yang terdapat pada tugas pertama, sehingga khalifat Allah fi sal-ard/termasuk amanah hamba Allah. D engan demikian tujuan hidup manusia harus diarahkan untuk mendapatkan mardabellah(ridha Allah) dalam bentuk segala aktivitas yang sesuai dengan tuntutan-Nya.

Pemahaman keempat dari IsamicWoddkiewadalah konsep Islam tentang alam semesta (baca harta). Seorang khalifah harus menyadari dengan baik tentang konsep isikhlaf sebagai sebuah kesadaran bahwa segala sesuatu yang diciptakan Allah Swt adalah mutlak milikNya. Manusia dalam pemahaman ini hanya sebagai makhluq yang diberikan amanah dalam mengelola bumi dan segala isinya.

"dan nafkahkanlah sebagian hartamu yang Allah telah menjadikan kamu menguasainya (mustakhlafin fib)." (Q.S. 57:7) ${ }^{23}$

Pengaruh istikhlaf ini bagi manusia dalam perekonomian secara langsung telah membawa dampak positif, di antaranya: patama mengurangi sikap sombong dan bangga yang merupakan sifat manusia di mana pemilik harta lupa daratan dan semena-mena terhadap hartanya; kedua, harta dianggap masalah yang ringan bagi pemiliknya sehingga pemilik itu dengan mudah mengeluarkan harta itu; memudahkan golongan kaya untuk menerima perintah dan patuh terhadap undang-undang karena perintah itu turun dari pemilik harta yang sebenarnya; ketiga, pemikiran istikhlaf dapat dijadikan landasan teori; keempat, memberikan keabsahan bagi jamaah yang beriman untuk mengawasi orang kaya yang melampaui batas dalam memperlakukan kekayaannya; kdima, menguatkan hati fakir miskin dan membenarkan tindakan mereka dalam meminta hak dari orang kaya.

D alam konteks ekonomi inilah, ada tuntutan dari Allah Swt bahwa dalam menjalankan

\footnotetext{
${ }^{21}$ Lihat al-Qur'an (Q.S 16:36, 21:25

${ }^{22}$ Lihat al-Qur'an (Q.S33:21, 4:65

${ }^{23}$ Maksud menguasai di sini adalah manusia bukan pemilik harta mutlak, tetapi wakil Allah yang bertugas sebagai pemelihara dan pengawas hartaitu (Q ardhawi, 2001).
} 
aktivitas ekonomi tidak seharusnya kita merusak alam sekitar. Menjalankan bentuk apapun aktivitas ekonomi harus betul-betul memahami konsep-konsep yang telah diterangkan di atas. Sebagai wakil Allah (khalifat Allab) di muka bumi ini, sudah seharusnya kita mengikuti apa yang diinginkan oleh Allah Swt. Sebagaimana halnya seorang direktur yang mewakilkan tugasnya kepada wakilnya. A kan terjadi sistem revarddan punishmentketika yang diperintahkan tidak sesuai dengan apa yang dilakukan (Q.S. 102:8).

Interaksi antara manusia, yang memiliki pemahaman komprehensif tentang konsep tawhild, konsep nubumwah konsep khalifat Allah termasuk konsep tentang alam (baca sumberdaya), dan alam inilah yang sesungguhnya menjadi tema sentral pembahasan tentang perekonomian. D engan pemahaman yang paripurna akan Isamic Wordkiew seharusnya pemanfaatan dan penggunaan alam beserta isinya seharusnya memberikan kemaslahatan maupun pencapaian falab/bagi seluruh umat manusia di dunia ini. Pemahaman pandangan ini pula seharusnya menjadi kerangka rujukan untuk aturan maupun cara pandang terhadap permasalahan-permasalahan ekonomi masyarakat.

Peran IsamicWoddkiewadalah sebagai nomativepimiplesyang bersumber dari al-Q ur'an dan al-Sunnah dieksplorasi dan dielaborasi oleh pendekatan uslibal-figh (mthoddogical justification) yang kemudian menghasilkan bingkai nomativejustificationdalam bentuk fiqhmıanalah untuk aspek-aspek yang berkaitan dengan perilaku ekonomi masyarakat. Usłlal-fiqhmenjadi sangat penting fungsinya sebagai alat justifikasi apakah praktek atau teori ekonomi sejalan dengan prinsip-prinsip sharish yang ada dalam al-Q uran dan al-Sunnah. ${ }^{24}$

Ada dua hal yang harus dipahami dengan cermat kalimat pada paragraph diatas; petama, Islam sebagai jalan hidup (way of life) dengan berpandukan al-Q ur'an dan al-Sunnah mengandung prinsip-prinsip ekonomi. Dalam proses menemukan ${ }^{25}$ (bukan menciptakan) prinsip-prinsip ekonomi maupun hukum muamalah (fich muanalah) dalam kedua sumber tadi perlu terus dilakukan dalam rangka memastikan pencapaian falabjberikut pelestariannya. Nomativejustification bisa ditemukan melalui pendekatan deduktif maupun induktif. Tradisi inilah yang selama ini dilakukan oleh para ulama klasik maupun kontemporer untuk mendapatkan justifikasi ilahiah dari al-Q ur'an dan al-Sunnah. Pada tahapan ini, proses ilmiah dengan metode usklibal-figh yang berkaitan dengan penemuan nomative justification akan senantiasa berlangsung seiring dengan perkembangan aktivitas ekonomi manusia.

Keelua, sebagai sebuah sistem, ekonomi Islam memiliki peran yang tidak hanya memiliki peran pemberi "stempel" halal. Lebih dari itu ekonomi Islam sebagai sebuah ilmu berusaha untuk memahami persoalan ekonomi dan perilaku manusia dalam sudut pandang shariłah. Pada gilirannya proses ini memungkinkan munculnya penemuan formulasi atau teori-teori ekonomi yang mempertimbangkan opini-opini sharisah. Pada poin inilah K han menambahkan bahwa kolaborasi maksimal antara ulama (religias schdars) dengan ekonom sangat mutlak diperlukan dalam kondisi sekarang dalam rangka mengembangkan ekonomi Islam.

Selain dari pertimbangan kedua sumber di atas, proses ilmiah tersebut juga

${ }^{24}$ D engan ilmu usileal-fiqh dapat diketahui kaidah-kaidah, prinsip-prinsip umum shari at Islam, cara memahami suatu dalil dan penerapannya dalam kehidupan manusia sehingga menghasilkan fiqih mu'amalah yang berkaitan dengan perilaku ekonomi masyarakat.

${ }^{25}$ Yang menciptakan adalah Allah Swt. Ayat-ayat Qawhixahmaupun Kawniyahtelah Dia ciptakan untuk kepentingan hidup manusia di dunia. Manusia diberikan akal untuk menemukan tanda-tanda tersebut untuk dirangkai menjadi teori maupun praktek dalam kehidupan nyata. 
mengakomodir pengalaman-pengalaman yang berkaitan dengan pemikiran atau praktek ekonomi yang pernah terjadi dalam sejarah ekonomi Islam. Banyak pemikiran maupun praktek ekonomi Islam yang bisa dijadikan obyek pembelajaran maupun alat pembanding dalam menemukan formulasi atau teori ekonomi yang sesuai dengan kondisi masyarakat kontemporer. Banyak hal yang bisa kita pelajari dari butir-butir sejarah yang tertuang dalam karya-karya fenomenal para ulama terdahulu seperti Ibn Khaldun, al-Maqrizi, al-G hazali, Abu Ubaid, IbnTaimiæah dan lain sebagainya.

\section{Gambar Pengembangan Konstruksi Ekonomi dalam Paradigma Islam}

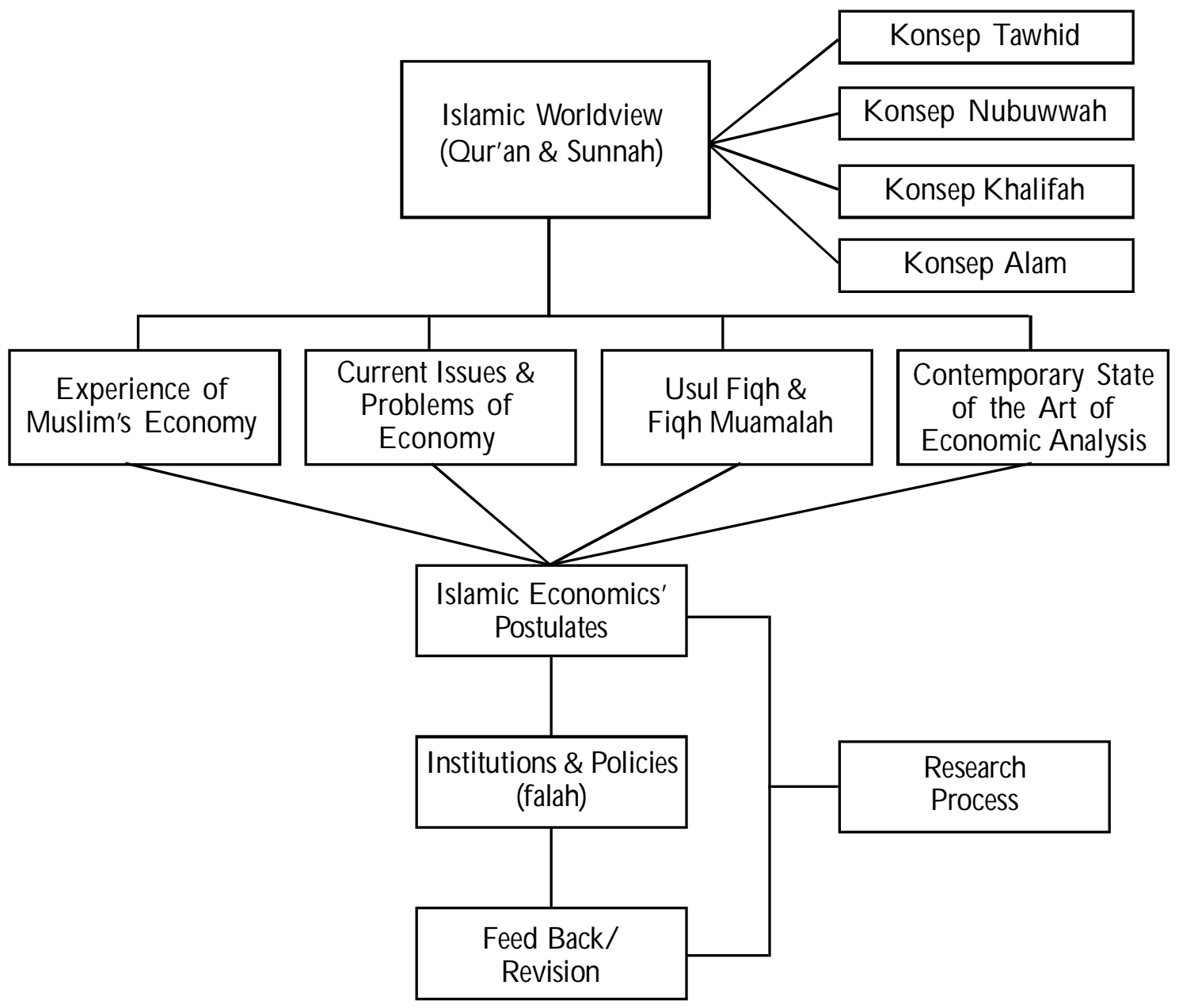

Sumber: Diformulasikan penulis dari beberapa sumber

Yang tidak kalah penting lagi adalah peran metodologi ilmiah kontemporer yang bisa dimanfaatkan dalam rangka menemukan formulasi ekonomi Islam tadi. Tren penelitian untuk praktek ekonomi Islam sekarang sudah banyak yang menggunakan alat analisa modern baik yang bersifat kualitatif maupun kuantitatif. Tantangan berikut setelah ditemukannya formulasi ekonomi Islam adalah peluang atau kemungkinan formulasi tersebut untuk dijadikan kebijakan atau praktek masyarakat sebagai bentuk wasilah atau mekanisme pencapaian falaby 
Jika peluang tersebut bisa direalisasikan dalam praktek masyarakat maupun kebijakan Negara (contoh bank shariłah, asuransi shariłah dll), maka tujuan mulia berikutnya adalah proses deek dan belancedalam bentuk penelitian. Studi empiris menjadi sangat krusial. Proses penelitian ini berperan untuk memastikan apakah sebuah formulasi yang dipraktekkan tersebut sudah sesuai dengan sharish (shari'gh compliance) atau memberikan efek positif bagi pencapaian falaby Pada tahap ini, jika formulasi atau teori tersebut tidak sesuai dengan shariła atau bahkan berdampak buruk bagi masyarakat, maka akan terjadi proses revisi dan reformulasi. D emikianlah gambaran konstruk sebuah proses di mana pengembangan ekonomi Islam sebagai sebuah sistem nilai dan sistem analisis diharapkan terus berlangsung dalam rangka memastikan pencapaian falah)sekaligus upaya untuk melestarikannya.

\section{Perbandingan Ekonomi Konvensional dan Ekonomi Islam}

Pembahasan pada bagian ini mencoba untuk membuat perbandingan Ekonomi Islam dan Ekonomi Konvensional. Pembahasan ini menjadi penting dalam rangka mempertegas posisi Ekonomi Islam sebagai sebuah sistem nilai maupun sistem analisis (ilmu ekonomi Islam). Sesungguhnya untuk membahas sekaligus menegaskan posisi Ekonomi Islam jika dibandingkan dengan Ekonomi Konvensional bisa ditarik benang merahnya dari paparan di bagian sebelumnya.

Pendekatan pembeda pertama bisa dicermati dari pemahaman cara pandang terhadap dunia (wordkient yang diungkap oleh kedua sistem tersebut khususnya yang berkaitan dengan alam beserta isinya. D engan kata lain, sesungguhnya perbincangan tentang paradigma sistem ekonomi harus dimulai dari pandangan dasar terhadap sumber daya atau harta kekayaan. Siapakah sesungguhnya pemilik alam semesta beserta isinya ini? Bagaimana posisi manusia dalam menyikapi alam beserta isinya? Patutkah manusia bertindak sekehendaknya dalam rangka memenuhi semua kebutuhan dan keinginan hidupnya? Jawaban dari pertanyaanpertanyaan inilah yang kemudian akan membedakan konsep produksi, komsumsi dan distribusi kedua konsep tersebut.

Interaksi antara manusia, yang memiliki pemahaman komprehensif tentang konsep tawhild, konsep nubumwah konsep khalifat Allah termasuk konsep tentang alam (baca sumberdaya), dan alam inilah yang sesungguhnya menjadi tema sentral pembahasan tentang perekonomian. D engan pemahaman yang paripurna akan Isamic Wordkiew seharusnya pemanfaatan dan penggunaan alam (produksi, konsumsi dan distribusi) beserta isinya seharusnya memberikan kemadahatan maupun pencapaian falab/bagi seluruh umat manusia di dunia ini. Pemahaman pandangan ini pula seharusnya menjadi kerangka rujukan untuk aturan maupun cara pandang terhadap permasalahan-permasalahan ekonomi masyarakat.

Pendekatan lain yang bisa digunakan adalah dengan melihat perbedaan antara ekonomi Islam dan konvensional dari sisi sebagai ilmu. Sebagai sebuah ilmu, kedua sistem tersebut bisa dicermati dari pendekatan yang sering digunakan dalam filsafat umum. yaitu pendekatan ontologis, epistemologis, dan aksiologis.

Pendekatan ontologis dijadikan sebagai acuan untuk menentukan hakikat dari ilmu ekonomi Islam, dan mengapa ia dibutuhkan. Sedangkan pendekatan epistemologis dipergunakan untuk melihat prinsip-prinsip dasar, ciri-ciri, dan cara kerja ilmu ekonomi 
Islam. D an pendekatan aksiologis diperlukan untuk melihat fungsi dan kegunaan ilmu ekonomi Islam dalam menyelesaikan berbagai persoalan yang dihadapi manusia dalam kehidupan sehari-hari.

1. Aksiologis

Secara aksiologis memang perlu diakui bahwa pembahasan kedua ilmu ekonomi tersebut cenderung memiliki fungsi yang sama yaitu bertujuan untuk membantu manusia dalam memenuhi kebutuhan hidupnya. Lewat berbagai macam tods yang tersedia, kesamaan-kesamaan pada sebagian kaidah kedua ilmu ekonomi tersebut dalam mengatasi persoalan ekonomi memang merupakan sebuah kecenderungan umum dalam aktifitas ekonomi yang sifatnya sunmat Allah Walaupun demikian ini tidak mutlak karena secara prinsipil ekonomi konvensional lebih mengedepankan memenuhi keinginan dimensi dunia dan materi belaka, sehingga cenderung individualis. Sedangkan dalam ekonomi Islam terdapat fungsi sosial lewat berbagai macam aktivitas seperti zakat, wakaf, dan infaq yang memang secara inheren merupakan bagian dari pelaksanaan ibadah kepadaNya.

Ekonomi konvensional menganggap manusia adalah homoeconmias yaitu perilaku ekonomi manusia yang mengedepankan rasio akal sesuai keinginan manusia sendiri. Secara sederhana perilaku manusia sebagai individu ekonomi menurut ekonomi konvensional memiliki sifat-sifat Pefet seff-interest dan Pefeet rationality. Karena itu wajar jika secara aksiologis, fungsi ilmu ekonomi hanya semata mengikuti keinginan manusia dengan aturan manusia itu sendiri.

D an HomoEconomias menjadi sangat tidak realistis ketika kita elaborasi lebih jauh prinsip-prinsip utamanya:

Prinsip Pertama: pefeet saff interet. Sifat manusia yang dianggap pefeet seff interest ini dipelopori oleh F.Y. Edgworth (1881) yang mengemukakan motif seff intereet (egism dan utilitarianism) dari prilaku ekonomi manusia. ${ }^{26}$ Edgeworth mengatakan bahwa prinsip utama ilmu ekonomi dari pihak manapun adalah digerakkan oleh kemauan untuk memenuhi kebutuhan pribadi semata. Karena itu Utility individu tidak tergantung pada utility pihak lain.

Padahal dalam kenyataannya manusia tidak sepenuhnya ego sdf-intereted Secara fitzah manusia memiliki sifat-sifat sosial yang baik seperti kasih sayang, cinta, belas kasih, dll. Hal ini ditunjukkan pula oleh perilaku altnistic seperti danity, vdunteerism memberi bantuan tanpa balasan, parenting dan bahkan mengorbankan diri untuk kepentingan negara. D an pemenuhan prinsip self-interest sendiri dapat mengarah ke perilaku sdf-de strutiveseperti penyalahgunaan obat, ketergantungan yang berbahaya, negative risk-taking, bunuh diri, dan sebagainya.

Islam memfasilitasi sifat altruisticmanusia dengan anjuran untuk berinfak/ berzakat. Bahkan sebagai suatu ibadah, zakat menjadi bagian salah satu rukun Islam yang lima, seperti diungkapkan hadith Nabi riwayat Mus'id al-Sa'dani al-Arbałin al-Nawawiyah, 1994) sehingga keberadaannya dianggap Malummin al-dix bi al-danurah (diketahui secara otomatis adanya dan merupakan bagian mutlak dari keislaman, Ali Yafie,1994).

D alam al-Q ur'an terdapat 82 ayat yang menyejajarkan sł̣lat dengan kewajiban zakat

${ }^{26}$ F.Y Edgeworth, "Mathematical Psychic: An Essay on the Application of Mathematics to the Moral Sciences" (1881, London) Lihat juga http:// homepage.newschool.edu/ het/ / profiles/ edgew.htm 
dan anjuran berinfaq, dan satu kali disebutkan dalam konteks yang sama akan tetapi dalam ayat berbeda, yaitu Surat al-Mu'minun ayat 2 dengan ayat $4 .{ }^{27}$

Prinsip kedua: Pefeet Rationality. Salah satu penyebab mengapa pendukung ekonomi konvensional begitu mengedepankan rasionalitas manusia karena teori dan kebijakan yang dikembangkan dilakukan dalam masyarakat yang berada dalam perilaku sekularisme. Sehingga norma dan etika spiritual dianggap bagian dari faktor cteis paribus yang berarti tidak mempengaruhi prilaku manusia dalam aktivitas ekonominya.

Darwin mendefinisikan rationalitas manusia didasarkan usaha untuk melayani kepentingan pribadi. Ia terbatas pada nilai keduniaan, itu makanya parameter dan tujuan aktivitas berekonominya cenderung materialistis. Konsep utilitas dalam prilaku konsumsi yang ditunjukkan oleh besar atau banyaknya barang dan jasa yang dikonsumsi dan konsep profit maximization dalam prilaku produksi menunjukkan warna materialisme dalam aktivitas ekonomi konvensional.

Kondisi tersebut bertentangan dengan kesepakatan terhadap ilmu sosial pada umumnya seperti sosiologi dan antropologi, di mana diyakini bahwa perilaku manusia seringkali adalah rumit, seff-contradidary, dan unpredidable D an ini terbukti secara empirik di mana pada kenyataannya memang manusia demikian adanya.

Muncul pertanyaan mengapa Ilmu Ekonomi menggunakan HomoEconomiassebagai landasan dasar prilaku konsumen? Alasan utama adalah karena Homo ecnomias ingin membuat analisis ekonomi menjadijauh lebih sederhana dengan mengesampingkan faktorfaktor sebagai makhluk ciptaan Tuhan yang menimbulkan konsekuensi kewajiban menjalankan aturanNya.

Menjelaskan perilaku manusia dalam dunia nyata adalah sangat sulit. Sehingga penganut prinsip HomoEconmiasmenyederhanakan hal ini dengan cara menyederhanakan manusia itu sendiri. Dua asumsi sifat manusia di atas yang menganggap manusia adalah memiliki rasionalitas sempurna sehingga akan terus memenuhi keinginannya menunjukkan hal tersebut.

Penyederhanaan ini memungkinkan Ilmu Ekonomi menjadi disiplin ilmu yang lebih predictablekarena manusia dianggap pasti akan terus memenuhi keinginannya tanpa peduli aturan dari sang Pencipta. Karena itu manusia adalah rational maximizes, sehingga menjadi mungkin untuk menjelaskan preferensi mereka secara numerik. Misalkan, Rp 1 juta pasti lebih disukai daripada Rp 500 ribu di manapun dan dalam konsidi apapun (Moreis better than less). ${ }^{28}$

Penggunaan model homo economiasini memang membuat analisa ekonomi menjadi lebih sederhana dan mengizinkan para ahli ekonomi mendapatkan hasil yang membenarkan dugaan awal mereka, namun hal ini akan membawa pada kesimpulan yang melenceng jauh dari kenyataan empirisnya. Karena itu kita perlu meletakkan landasan dasar prilaku manusia ke asalnya yang hakiki sesuai ketentuanNya.

2. Ontologis

D alam perspektif ontologis, ilmu ekonomi Islam semakin jelas sangat berbeda dengan ekonomi konvensional. Secara hakikat ilmu, ilmu ekonomi Islam membahas dua

${ }^{27}$ LihatYusuf Q ardhawi, Fiqhal-Zakah(Beirut: Muassasah al-Risakah 1985.

${ }^{28}$ Lihat Roberst SPyndick et.al, Miøaecnamis AnAsianPespeetive(Singapore: Prentice Hall 2006), 66. 
disiplin ilmu secara bersamaan. Kedua disiplin ilmu itu adalah ilmu ekonomi murni dan ilmu fiqih mu'amalat. D engan demikian, dalam operasionalnya ilmu ekonomi dalam perspektif Islam akan selalu menyandarkan segala analisis ekonomi pada pedoman alQ ur'an dan Hadith Nabi Saw. Terdapat kaidah "asal dari segala sesuatu adalah dibolehkan kecuali ada sebuah dalil yang mengharamkannya," sehingga tafsiran ilmu ekonomi tidak semata berdasarkan pemikiran rasional saja, ia harus memiliki justifikasi yang kuat berdasarkan prinsip shariłah.

Hal ini dapat kita lihat secara sederhana terhadap cara pandang permasalahan ekonomi seperti berikut. Ilmu ekonomi secara dasar memokuskan upaya untuk memecahkan fakta bahwa ada perbedaan antara kelangkaan sumber daya dengan kebutuhan dan keinginan untuk menggunakan sumberdaya tersebut.

Secara umum dalam konsep ekonomi konvensional perspektif yang dibangun adalah adanya kondisi sumber daya yang bersifat terbatas, limited resarces tetapi di sisi lain kebutuhan dan keinginan manusia bersifat tak berhingga, unlimited wants

D ari kedua kondisi tersebut, keinginan yang tak terbatas bersifat given dalam arti secara teoritis pembahasan yang dibangun tidak mempertimbangkan kemungkinan adanya keinginan yang tak terbatas sebagai sebuah masalah, tetapi hanya memokuskan pemecahan permasalahan ekonomi pada scarrity, sebagai konsekuensi sumber daya yang terbatas.

Pada sisi yang lain Pemikiran secara Islami memandang penyebab dan hal yang terkait mengapa ilmu ekonomi dibutuhkan, sama dengan pemahaman yang diberikan pemikiran konvensional. Islam memandang bahwa masalah dasar ekonomi terletak pada kondisi sumber daya yang terbatas untuk memenuhi kebutuhan dan keinginan manusia yang tidak terbatas.

Secara parsial dan lokal scardity sangat mungkin, dan ini terbukti secara empiris adanya kondisi kelangkaan sumber daya alam tersebut. ${ }^{29}$ Walaupun kita menyetujui bahwa secara keseluruhan total ketersediaan sumber daya akan seimbang dengan permintaan manusia (Allah Swt menciptakan segala sesuatu sesuai ukurannya), tetapi terkait dengan ruang dan waktu kondisi ketidakseimbangan dapat terjadi. Sebagai contoh terkait dengan keterbatasan ruang, adanya kondisi di benua Afrika yang sebagian besar masyarakatnya memiliki masalah kekurangan bahan makanan pokok. Atau untuk contoh keterbatasan karena waktu: Indonesia yang pernah berswasembada beras, dan pernah sebagai salah satu pengekspor utama minyak, saat ini telah menjadi importer untuk kedua komoditi tersebut. Artinya ada seiiring berjalannya waktu terdapat perubahan kondisi yang membuat kekurangan dan kelangkaan sumber daya menjadi tak terhindarkan.

Pemikiran Islami juga berpendapat bahwa keinginan manusia memang relatif tak terbatas dalam arti terdapat kecenderungan manusia untuk terus merasa tak terpuaskan. ${ }^{30}$ Tetapi hal ini tidak bersifat given sebagaimana yang diproposisikan oleh ekonomi konvensional. Justru dalam ekonomi Islam ada aturan main, dan tuntunan bagaimana sepatutnya manusia berprilaku untuk memenuhi keinginannya tersebut. Sehingga ekonomi Islam menjadi dibutuhkan manusia untuk mencapai hakikat manusia yang sesungguhnya, dan aturan main tersebut, dalam kaitannya dengan hubungan antar manusia, diatur dalam

${ }^{29}$ Lihat al-Qur'an 2 (al-Baqarah): 154.

${ }^{30}$ Lihat al-Qur'an (al-Takathur): 1-5. 
fiqih mu'amalat.

Manusia diarahkan agar dapat mengontrol keinginan sebatas kebutuhan yang memang diperlukan. Karena itulah keinginan dan kebutuhan adalah dua hal yang berbeda dalam Islam. Manusia dalam memenuhi kebutuhannya diarahkan sesuai maqajidal-shan' 'ah di mana ini menjadi alat untuk menentukan kebutuhan berdasarkan skala prioritas.

3. Epistemologis

Begitu pula dari aspek epistemologis atau prinsip-prinsip dasar, ciri-ciri, dan cara kerja ilmu ekonomi. Mengutip pernyataan Yusuf Q ardhawi, Ilmu ekonomi Islam memiliki tiga prinsip dasar yaitu Tauhid, Akhlaq dan Keseimbangan. D ua prinsip yang pertama kita sama-sama tahu pasti tidak ada dalam landasan dasar ekonomi konvensional. Prinsip keseimbangan pun dalam prakteknya justru yang membuat ekonomi konvensional semakin dikritik dan ditinggalkan orang. ${ }^{31}$

Perbedaan ciri-ciri akan lebih mudah kita lihat dari beberapa pembahasan sebelumnya. D alam konteks ini perbedaan antara ekonomi Islam dan ekonomi konvensional tidak hanya sebatas pelarangan riba plus zakat, akan tetapi perbedaan tersebut akan lebih menyolok ketika dilihat secara kritis dari perspektif filsafat ilmunya. Shuraticproessyang diproposisikan Choudury, misalnya, menjadi pembeda lebih lanjut dari cara kerja ilmu ekonomi Islam.

Pembahasan lebih lanjut terhadap aspek epistemologis akan membawa kita pada kajian lebih lanjut dari ekonomi Islam. Artinya ia akan melebar ke bagian-bagian teori ekonomi yang lebih lanjut akan dibahas pada dikotomi mikro-makro, kebijakan moneter, fiskal, public podio dan sebagainya.

\section{Kesimpulan}

Ekonomi Islam merupakan bagian integral dari sistem ajaran Islam. Dia merupakan ekonomi ilahiah, karena titik berangkatnya dari Allah, tujuannya mencari rida $>$ Allah dan cara-caranya tidak bertentangan dengan shari at-Nya. Dia bukan lahir sebagai produk alternatif dari sistem yang sedang berlaku sekarang (baca sosialis maupun kapitalis), tetapi merupakan sumat Allah (ketetapan Allah) yang seharusnya diaplikasikan di sepanjang lembaran sejarah peradaban manusia. Ekonomi Islam mengandung dua pemaknaan sekaligus; yaitu sebagai sistem nilai maupun sebagai sistem analisa (ilmu). Untuk penjelasan yang terakhir, di mana proses analisa maupun kajian terus berlangsung, tentunya akan selalu bersinggungan dengan metodologi. D alam konteks ini, peran metodologi sangat signifikan dalam rangka mengembangkan analisa atau studi tentang ekonomi Islam dan segala turunannya. Jika ilmu ekonomi melakukan analisis dengan berupaya mencarikan solusi pemecahan permasalahan yang dihadapi umat berupa penemuan formulasi, strategi, kebijakan, maka fiqih akan meresponnya dengan memberikan rekomendasi dari solusi yang ditawarkan oleh ilmu ekonomi sesuai dengan magasid al-shariła (tujuan shariðah) yang dijustifikasi oleh fiqih. Interaksi ini, antara fiqih dengan ilmu ekonomi, pada gilirannya akan meningkatkan pemahaman yang lebih terhadap persoalan masing-masing. Pada akhirnya akan menciptakan suatu perkembangan yang terkoordinasi antara ekonom muslim yang mempelajari ilmu ekonomi dengan fugaha'’yang ahli dalam fiqih. Pada gilirannya, proses

\footnotetext{
${ }^{31}$ Ini dapat dilihat dari realita ketimpangan ekonomi dunia, kemiskinan, pengagungan K apital, dsb.
} 
tersebut memberikan porsi terjadinya konsep integrasi ilmu dengan menafikan adanya dikotomi antara religias scienes dan wordy sienes Faktor pembeda antara ekonomi Islam dan ekonomi konvensional bisa ditelusuri dari pemahaman yang komprehensif tentang konsep pandangan dunia yang berkaitan dengan pembahasan konsep Tawhid, Nubumwah, Khalifah dan Alam. Sebagai sebuah sistem nilai maupun sistem analisis (ilmu), ekonomi Islam juga bisa dikaji visauisdengan ekonomi konvensional dengan pendekatan filasafat pada umumnya. Untuk yang terakhir, pembahasan tersebut sangat berkaitan erat dengan pendekatan ontologis, epistemologis dan aksiologis yang kesemuanya mengarah kepada kepastian Ekonomi Islam sebagai ilmu yang kokoh.

\section{Daftar Rujukan}

Anwar, Muhammad. "Islamic Economic Methodology," dalam Essays in Isamic Economic Amalysis (Ed). FR. Faridi. New D elhi, 1991.

Chapra, Mohammad Umar. What is Isamic Economics?. Jeddah, Saudi Arabia: IRTI- ID B, 1996.

Faruqi (al), Ismail Raji. Isamization of Knontedge Prddens, Priniples and Prospetive USA: IIIT, 1982.

Khan M. Akram. An Introdution to IdamicEconomics Islamabad: IIIT, 1994.

Mannan, M.A. Ekanom Isam Teen dan Praktdk. Jakarta: PT Intermasa, 2004.

Mannan, Muhammad Abdul. The Making of Isamic Econmic Socidy. Jeddah, Saudi Arabia (International Center for Research in Islamic Economics, King Abdul Aziz University (KAU), 1984/ 1404H.

Pyndick et.al, Robert S. Miaceconomics An Asian Pesspetive Singapore: Prentice Hall 2006. Q ardhawi (al), Yusuf. Peran Nilai dan Maral dalamPerkanomian Isam Jakarta: Robbani Press 2001.

Shatibi (al)>Kitab al-Muwafaqaat, Juz I

Syafi'i Antonio, Muhammad Syafi'i. Bank Syaniah dari Teer kePraktak. Jakarta: G ema Insani Press 2001.

Syarifuddin, A mir. Ushul Fiqh Jilid I. Jakarta: Logos, cet I, 1997.

Yafie, Ali. Menggagas Fiqih Sosial. Bandung: Mizan 1994.

Yusuf Q ardhawi, Yusuf. Fiqh Zakat. Beirut: Muassasah al-Risałah 1985.

Zarqa, Muhammad Anas. Islamization of Economics TheConcept and Methoddogy, J. KAU., Vol. 16, No. 1. 